\title{
Interaction Between Knowledge Management Practices, Innovation and Job Creation in the Niger Delta Development Commission (NDDC), Nigeria
}

\author{
Rosaline Opeke ${ }^{1} \quad{ }^{2}$ Bright-Light Felix Allen ${ }^{1} \quad$ Jacob Opele $^{2}$ \\ 1.Department of Information Resources Management, Babcock University, Ilishan-Remo, Ogun State, Nigeria \\ 2.National Centre for Technology Management (NACETEM), Obafemi Awolowo University, Ile-Ife, Nigeria
}

\begin{abstract}
Knowledge and its management are essential tools for job creation, economic growth, and development. Despite its importance, not many organizations are making adequate use of their knowledge assets. The current study examined the influence of knowledge management practices and innovation on job creation in the Niger Delta Development Commission (NDDC), Nigeria. The study adopted the survey research design. 440 out of the population of 879 employees of the commission was used for the study. Data analysis was done using descriptive and inferential statistics such as percentage distribution, mean and standard deviation as well as regression analysis. The findings revealed an overall moderate extent of job creation in the Niger Delta region of Nigeria, it indicates a high extent of knowledge management practices, it shows a high extent of innovation management practices. The study concluded that knowledge management processes were a significant predictor of job creation in the region (Adjusted $\mathrm{R}^{2}=.413, \mathrm{~F}_{(1,306)}=217.418, \mathrm{P}<.05$ ). It was recommended that authority of the Niger Delta Development Commission (NDDC) should strive to maintain their level of knowledge and innovation management practices with a view to improving employment generation and general development of the area.
\end{abstract}

Keywords: Knowledge management, Practices, Innovation, Job creation

DOI: $10.7176 / \mathrm{IKM} / 9-2-05$

\section{Introduction and Review of Related Literature}

Knowledge and its management are essential tools for economic growth and development. Knowledge is the insights, understandings, and practical know-how that people possess. It is a fundamental resource that allows people to function intelligently. Knowledge refers to an invisible or intangible asset, in which its acquisition involves complex cognitive processes of perception, learning, communication, association and reasoning (Epetimehin \& Ekundayo, 2011). Knowledge is considered the most important organizational resource needed for sustainable business and economic development. Knowledge management (KM) is systematic management that consists of the process of making, collection, arranging, disseminate and making use of knowledge to create business value and gaining a competitive advantage (Omotayo, 2015). It is an application which is modern and based on technological working and focusing on knowledge and alignment with decision making, evaluation and operative systems redesign (Kibet, Samuel, Magutu \& Richard, 2010).

According to Wong and Aspinwall (2006), knowledge management is an important process in which knowledge existing in an organization is transformed into innovation and economic value Innovation capabilities is conceptualized as the capacity of firm's to generate new ideas to improve their products, services, processes to enable them to enhance their organizational performance and attain competitive edge (Jantunen, 2005). With an innovative capability, a firm enhances their adeptness to gather and integrate knowledge to become rare, unique and difficult to imitate, thus enabling them to develop the capacity to sustain a high level of competitive advantage.

Pancholi and Amrata (2014) explained that the implementation of knowledge management in an organization involves the integration of knowledge from the domains of strategy, structure, processes, and technology, thereby making it a strategic tool for sustainable business process and product development for commercialization. However, to ensure an effective business process or product development, there is a need for a structured knowledge management process approach to be followed. Knowledge Management Process (KMP) entails the various stages of knowledge development, refinement, application, and utilization in an organization for the tactical or strategic accomplishment of specific goals and objectives. The World Intellectual Property Organization (WIPO) (2015) defines knowledge management as "a discipline that promotes an integrated approach for the identification, capture, retrieval, distribution, sharing, use and reuse of information and knowledge assets" (WIPO, 2015).

The United Nations Development Programme (UNDP) defines knowledge management as "the summary of all measures designed to address its knowledge-related challenges" and recognizes that knowledge is both "a key output that it delivers to its clients, as well as a key resource that the organization needs in order to deliver its results" (UNDP, 2014) For the United Nations Educational, Scientific and Cultural Organization (UNESCO), 
"the establishment of a knowledge management system involves enhancing knowledge generated during project and programme implementation under a systematic, coherent and predefined approach" (UNESCO, 2012). IAEA (2013) considers that "corporate knowledge management is an essential component of quality management and the key to quality performance in the Agency". The corporate knowledge management policy "enables the Agency to create, acquire, capture, codify, store, retain, share, use and transfer knowledge".

The need for KM in job creation is the realization that an organization must manage its knowledge if it is to survive in today's dynamic and competitive marketplace. Desouza (2011) posited that without adequate care in how knowledge is recruited and managed, organizations will not be operating optimally and this will result in the ineffective and inefficient creation and delivery of products and services leading to unsatisfied customers. The link between knowledge and innovation in job creation cannot be overemphasized. Innovation management describes the decisions, activities, and practices that move an idea to realization for the purpose of generating business value. Innovation management is basically the combination of the management of innovation processes and change management in an organization. This management refers both to the product, business processes and organizational innovations aimed at developing the organization strategic assets. Innovation management allows the organization to respond to external or internal opportunities, and use its creativity to introduce new ideas, processes or products.

The innovation processes include idea identification and generation, concept development, concept feasibility determination, exploitation and execution, feedback and refinement, and deployment and launch. The Innovation management processes use a form of project/product development life cycle method as an approach to develop a new project/product or to modify an existing one. Khurana and Saini (2017) described innovation as the introduction or launching of something new into socio-economic spheres for some use or application that will provide sustainable business growth. Innovation is essential in an effort to develop a product or process and services that will revolutionize the business process of any organization. Also, Saini \& Khurana (2018) asserts that in the last few decades, business model innovation has assumed increasing significance which fosters innovation in two ways: (a) allowing managers and entrepreneurs to connect innovative products and technologies to realize output in the market; (b) it may be also a source of innovation in itself. Business model innovations have the potential to revolutionize an entire industry.

Studies from Nigeria have shown that the innovative capability of firms is partly dependent on the educational qualification, experience and the technical improvement as a result of 'on-the-job' learning of its workforce (Romijn \& Albaladejo, 2002). In particular, firms could be seen as being able to learn faster and innovate more proficiently when their staffs are highly qualified and professionally experienced. A national innovation survey conducted by the National Centre for Technology Management (NACETEM, 2011) revealed that the rate of innovation in Nigeria was about $84 \%$. Their study indicates a higher rate of innovation within the service sector than manufacturing. This is not surprising considering the recent increased economic importance of services. It is projected to contribute about 35\% of Nigeria's GDP in 2011 (NBS, 2010) from 27\% in 1998. In all, about $83 \%$ of manufacturing enterprises in Nigeria were innovative, compared with about $87 \%$ of service enterprises. About $53 \%$ of all enterprises had both product and process innovations, while of the four types of innovations the non-technological innovations (marketing and organizational) appeared more pronounced in Nigerian enterprises. A total of about $58 \%$ of innovative enterprises reported ongoing innovation activities during the period (NBS, 2010).

With reference to innovation types, the Nigeria National Innovation Survey revealed that about $53 \%$ of firms in the manufacturing sector and $67 \%$ in the service sector had product innovations. About three-quarters of these originated within the country and were mainly developed within the firms (NACETEM, 2011). The same study revealed that less than $20 \%$ of the enterprises collaborated with other enterprises or institutions to develop product innovations, while less than $11 \%$ relied on other enterprises or institutions to develop their innovations. This implies that most enterprises in Nigeria are capable of developing their own products, services, and processes using available technologies instead of depending on foreign ones. It also shows a high internalization of a firm's innovation efforts. Investing in a firm's innovation capability is key to economic prosperity and business sustainability. To develop a firm's innovation capability, efforts must be made in managing all the innovation processes. The processes include idea generation, concept development, concept feasibility determination, exploitation, feedback, and implementation. Developing the innovation capability of a firm requires managing the innovation processes from ideation to product development and implementation. The aim of the innovation management process is to manage innovation from every stage to develop a new product, process or improved service that have the capability to expand the business process of the firm and to provide opportunities for gainful employment through job creation.

The first stage of the process of innovation management is idea identification and generation. At this stage, creative ideas are identified and generated within the organization and outside the organization in line with the organization's strategic business objective. The objective could be to develop a new project, or a new product, or a new process and even modification of an existing system. The ideas can be generated through Research and 
Development (R\&D), through brainstorming sessions and expert knowledge sharing, through open innovation practices, through extra-organizational knowledge sharing and through strategic alliances with innovative firms. This stage of the innovation management process requires strategic and creative thinkers, R\&D experts, knowledge managers and professionals in various fields of study related to the business objective.

\section{Research objective}

This study examined the following specific objectives:

1. determine the extent of job creation in the Niger Delta region by NDDC;

2. find out the extent to which knowledge management is practiced in the region by NDDC

3. investigate the extent to which innovation management is practiced by NDDC

4. ascertain the influence of knowledge management practices on job creation activities by the Niger Delta Development Commission

\section{Research questions}

1. What is the extent of job creation activities employed in the Niger Delta region by NDDC?

2. To what extent is knowledge management practiced in the Niger Delta region by NDDC?

3. To what extent is innovation management practiced in the region by the NDDC?

4. Knowledge management Practices have no significant influence on job creation by the Niger Delta Development Commission,

\section{Research setting}

This study was carried out in the Niger Delta region of Nigeria. The area which is described as the Niger Delta region of Nigeria lies between latitudes 4o and 60 North of the Equator and 4oand 8o east of the Greenwich. It comprises the states of Akwa Ibom, Cross River, Edo, Imo, Rivers, Bayelsa, Delta, Abia, and Ondo, making it coterminous with all of Nigeria's oil-producing states. Stretching over 20,000 km2of swamp land in the littoral fringes of the country, it embraces one of the world's largest wetlands, over $60 \%$ of Africa's largest mangrove forests, and one of the worlds' most extensive (Eyinla \& Ukpo, 2006). The Niger Delta region in Nigeria is wellknown for its huge presence of crude oil, the exploration of which has contributed to the nation's gross domestic products (GDP) on a large scale for the past six decades. In addition, more than $80 \%$ of the nation's infrastructural investments in the various sectors of our national economy depend largely on the income generated from the sales of oil exported from the Niger Delta Region. However, the deplorable state of the region led to the creation of the Niger Delta Development Commission (NDDC) as an agency of government in 2000. Its mission is to facilitate the rapid and even development of the well-endowed but highly beleaguered Niger Delta region of Nigeria (Ughakpoteni, 2012).

\section{Methodology}

This study adopted the survey research design. The method is considered appropriate in order to specify the accurate description of how knowledge management practices and innovation interact with (Job creation) in the Niger Delta Development Commission, Nigeria. The population for this study is made up of all staff in the head office and those in branches of the commission cutting across the directorates, the management staff, the senior non-management staff, and junior staff across the various departments of the Commission. In determining the sample size, a proportionately stratified sampling technique was used to obtain a representative sample from each level (management, senior-non management, and junior staff) in the commission. Thereafter, 440 out of the population of 879 employees of the commission was used for the study. The main instrument for data collection was a structured questionnaire. Ensuring face and content validity of the questionnaires involved a pilot study which was conducted among 30 Officers of the ministry of labor and productivity, Edo State. Reliability of the instrument was determined using a Cronbach's alpha of 0.7 and above was considered adequate for inter-item consistency among the items in the research instrument. The data collected were analyzed using descriptive and inferential statistics such as percentage distribution, mean, median and standard deviation. Regression analysis was used to establish the influence of the independent variable on the dependent variable. Specifically, regression analysis was used to test the hypothesis stated in the study. Statistical Package for Social Sciences (SPSS version 20.0) was used to analyze the collected data gathered in the course of the study.

\section{Results and Discussion}

The extent of job creation in the Niger Delta region by NDDC

Table 1 shows an overall moderate extent of job creation in the Niger Delta region of Nigeria with a mean of 2.49 on a scale of four points. Employment generation has the mean of (2.59) infrastructural investment and development (mean $=2.56)$, investment in small and medium enterprises (mean $=2.39)$, government hiring and recruitment $($ mean $=2.68)$, private sector recruitment $($ mean $=2.56)$ outsourcing of equipment $($ mean $=2.52)$. 
Others include investment in basic infrastructure $($ mean $=2.56)$, interest rate $($ mean $=2.44)$ youth empowerment programmes (mean $=2.46$ ) while interest rate reduction came has the mean of 2.44 on a scale of 4 points. The findings of this study agree with the study of the International Labour Organization (2017), which indicates that employment creation, the protection of workers' rights, social dialogue and social protection have long been issues of major concerns, and securing decent jobs for everyone remains the key strategic goal of every government. However, it has become increasingly clear that to achieve this goal, government and organizations will have to engage in active investments in the areas of infrastructure and human capital developments.

\section{The extent of knowledge management practices in the Niger Delta Region}

Table 2 shows a high extent of knowledge management practices (grand mean $=2.51$ ) on a scale of four points. The table It shows that the mean of Knowledge Utilization was (2.58), Knowledge Sharing/Dissemination (2.53), Knowledge Creation/Sensing Processes (2.46), Knowledge Capture/Organizing (2.46). It shows that knowledge utilizations contributed most to the knowledge management practices in the region with a mean of 2.58. This tallies with the report of the United Nations Educational, Scientific and Cultural Organization (UNESCO) which stipulated that "the establishment of a knowledge management system involves enhancing knowledge generated during project and programmes implementation under a systematic, coherent and predefined approach" (UNESCO, 2012). Similar findings were reported in the study of IAEA (2013) which revealed that "corporate knowledge management is an essential component of quality management and the key to quality performance in the Agency". According to them, the corporate knowledge management policy "enables the Agency to create, acquire, capture, codify, store, retain, share, use and transfer knowledge". In a related study, Rodrigo \& Manoel (2017) asserted that knowledge sharing and dissemination provide tools to collaborate, access and share the knowledge to develop into innovative projects that will fulfill specific objectives.

\section{The extent to which innovation management is practiced in the Niger Delta Region}

Table 3 shows a high extent of innovation management practices with a grand mean of 2.54 on the scale of 4 points. The observed innovation management practices include feedback/refinement which involved project monitoring and evaluation in the region, feedback on project progress and development, refinements and modification of projects for development and for empowerment in the region. The findings tallies with the study of Khurana and Saini (2018) which claimed that in the last few decades, business model innovation has assumed increasing significance that has fostered innovation in two ways: (a) allowing managers and entrepreneurs to connect innovative products and technologies to realize output in the market; (b) it may be a source of innovation in itself. The findings of this research show that innovation management is critical to organizational sustainability. Besides, the firm's innovation management provides corporate support functions in value chain management. Investment in a firm's innovation is widely publicized as the key to long-term economic prosperity, with the potential to drive future growth (Hamm, 2009).

It has been argued that without innovation, the economic and social pay-off of hardcore science and technology efforts of a nation would be diminished (NACETEM, 2011). Without innovation, science and technology become a mere academic exercise that lacks societal impact. The findings of this study agree with a study by Niek and Louis (2008) which investigated innovation management, using the innovation funnel as a tool to measure the innovation processes required for business growth and sustainable economic development. The study concluded that innovation management provides structure and discipline that facilitates the innovation process that allows faster development of innovations that drives growth and the development of new business areas that will create quality jobs for the unemployed. The findings also identified the innovation funnel as a strategic innovation management tool that top management can use in developing new processes or products and modifying existing processes for business growth and competitiveness.

\section{Knowledge Management Practices and Job Creation Activities in the Niger Delta Region}

Table 4 indicates that knowledge management processes was a significant predictor of Job Creation (Adjusted $\mathrm{R} 2=.413, \mathrm{~F}(1,306)=217.418, \mathrm{P}<.05)$. It reveals that $41.3 \%$ of the variation in the dependent variable (job creation) was accounted for by the independent variable knowledge management processes $(\mathrm{R} 2=.415, \mathrm{P}<.05)$. The result also indicates that an additional increase in knowledge management processes will lead to 0.648 unit of increase in Job Creation $(\beta=.648, \mathrm{p}<.05)$. 
Table 1: Extent of Job Creation activities in the Niger Delta

\begin{tabular}{|c|c|c|c|c|c|c|}
\hline Job creation activities & $\begin{array}{c}\text { Very } \\
\text { high } \\
\text { extent }\end{array}$ & $\begin{array}{c}\text { High } \\
\text { extent }\end{array}$ & $\begin{array}{c}\text { Moderate } \\
\text { extent }\end{array}$ & Low extent & Mean & SD \\
\hline \multicolumn{7}{|l|}{ Employment } \\
\hline Government hiring (recruitment) & $58(18.8)$ & $124(40.30$ & $95(30.8)$ & $31(10.1)$ & 2.6786 & .89366 \\
\hline Private sector hiring recruitment & $54(17.5)$ & $111(36.0)$ & $97(31.5)$ & $46(14.9)$ & 2.5617 & .94787 \\
\hline $\begin{array}{l}\text { Outsourcing of equipment purchase } \\
\text { and supply to vendors/contractors }\end{array}$ & $36(11.7)$ & $126(40.9)$ & $109(35.4)$ & $37(12.0)$ & 2.5227 & .85198 \\
\hline \multicolumn{7}{|c|}{$\begin{array}{lll} & \text { Average Mean } \text { Score }=2.59 \\
\end{array}$} \\
\hline \multicolumn{7}{|c|}{ Infrastructure Investment and Development } \\
\hline Investments in basic infrastructure & $65(21.1)$ & $111(36)$ & $88(28.6)$ & $44(14.3)$ & 2.6396 & .97024 \\
\hline Provision of educational facilities & $65(21.1)$ & $98(31.8)$ & $94(30.5)$ & $51(16.6)$ & 2.5747 & 1.00046 \\
\hline Provision of ICT Facilities & $42(13.6)$ & $107(34.7)$ & $127(41.2)$ & $32(10.4)$ & 2.5162 & .85594 \\
\hline Provision of medical facilities & $34(11)$ & $108(35.1)$ & $126(40.9)$ & $40(13)$ & 2.5000 & .85610 \\
\hline \multicolumn{7}{|c|}{ Average Mean Score $=\mathbf{2 . 5 6}$} \\
\hline \multicolumn{7}{|l|}{ Youth Empowerment Programs } \\
\hline $\begin{array}{ll}\text { Entrepreneurship } & \text { Development } \\
\text { Programs (EDP). } & \\
\end{array}$ & $42(13.6)$ & $112(36.4)$ & $119(38.6)$ & $35(11.4)$ & 2.5227 & .86714 \\
\hline $\begin{array}{l}\text { Rural agricultural development and } \\
\text { training programs (RADTP) }\end{array}$ & $41(13.3)$ & $100(32.5)$ & $120(39.0)$ & $47(15.3)$ & 2.4383 & .90570 \\
\hline $\begin{array}{l}\text { Vocational skills development } \\
\text { programs (VSDP) }\end{array}$ & $49(13.3)$ & $120(39.0)$ & $98(31.8)$ & $49(15.9)$ & 2.4253 & .91189 \\
\hline \multicolumn{7}{|c|}{ Average Mean Score $=\mathbf{2 . 4 6}$} \\
\hline \multicolumn{7}{|l|}{ Interest Rate Reductions } \\
\hline $\begin{array}{l}\text { Task free business operating for } \\
\text { indigenes }\end{array}$ & $69(22.4)$ & $74(24.0)$ & $97(31.5)$ & $68(22.1)$ & 2.4675 & 1.06877 \\
\hline $\begin{array}{l}\text { Given local business operators in } \\
\text { the Niger Delta reduced interest } \\
\text { rate on business transaction with } \\
\text { the commission }\end{array}$ & $56(18.2)$ & $84(27.3)$ & $109(35.4)$ & $59(19.2)$ & 2.4448 & .99847 \\
\hline $\begin{array}{l}\text { Provision of low costs loans to } \\
\text { indigenous business operators }\end{array}$ & $57(18.5)$ & $71(23.1)$ & $122(39.6)$ & $58(18.8)$ & 2.4123 & .99614 \\
\hline \multicolumn{7}{|c|}{ Average Mean Score $=2.44$} \\
\hline \multicolumn{7}{|c|}{ Investment in Small and Medium Enterprise } \\
\hline $\begin{array}{l}\text { Corporate investment into SMEs } \\
\text { generally in the zone }\end{array}$ & $43(14.0)$ & $90(29.2)$ & 122(39.6) & $53(17.2)$ & 2.3994 & .93062 \\
\hline $\begin{array}{l}\text { Provision of funding to SMEs in the } \\
\text { Niger Delta Region }\end{array}$ & $39(12.7)$ & $97(31.5)$ & $116(37.7)$ & $56(18.2)$ & 2.3864 & .92561 \\
\hline $\begin{array}{l}\text { Procurement of basic operational } \\
\text { materials in the commission } \\
\text { through SMEs }\end{array}$ & $29(9.4)$ & $97(31.5)$ & 144(46.8) & $38(12.3)$ & 2.3799 & .82025 \\
\hline \multicolumn{7}{|c|}{ Average Mean Score $=\mathbf{2 . 3 9}$} \\
\hline
\end{tabular}


Table 2: Extent to which knowledge management is practiced in the region by NDDC

\begin{tabular}{|c|c|c|c|c|c|c|}
\hline KMP employed & $\begin{array}{c}\text { Very high } \\
\text { extent }\end{array}$ & $\begin{array}{c}\text { High } \\
\text { extent }\end{array}$ & $\begin{array}{l}\text { Moderate } \\
\text { extent }\end{array}$ & $\begin{array}{l}\text { Low } \\
\text { extent }\end{array}$ & Mean & SD \\
\hline \multicolumn{7}{|l|}{ Knowledge Utilization } \\
\hline $\begin{array}{l}\begin{array}{l}\text { Determination of concepts feasibility for } \\
\text { developments }\end{array} \\
\end{array}$ & $54(17.5)$ & $119(38.6)$ & $99(32.1)$ & $36(11.7)$ & 2.6201 & .90700 \\
\hline Research and development project & $44(14.3)$ & $129(41.9)$ & $95(30.8)$ & $40(13.0)$ & 2.6201 & .90700 \\
\hline $\begin{array}{l}\text { Development of creative ideas into } \\
\text { products/projects concepts }\end{array}$ & $42(13.6)$ & $129(41.9)$ & $99(32.1)$ & $38(12.3)$ & 2.5682 & .87597 \\
\hline $\begin{array}{l}\text { Utilization of knowledge combined and } \\
\text { externalized for competitive business process } \\
\text { improvement in the commission }\end{array}$ & $62(20.1)$ & $96(31.2)$ & $100(32.5)$ & $50(16.2)$ & 2.5519 & .98881 \\
\hline \multicolumn{7}{|c|}{$\begin{array}{lll} & \text { Average Mean } \text { Score }=2.58 \\
\end{array}$} \\
\hline \multicolumn{7}{|l|}{ Knowledge Sharing/Dissemination } \\
\hline $\begin{array}{l}\text { Knowledge sharing through non- media (face- } \\
\text { to-face, etc. }\end{array}$ & $65(21.1)$ & $110(35.7)$ & $90(29.2)$ & $43(14.0)$ & 2.6396 & .96687 \\
\hline $\begin{array}{l}\begin{array}{l}\text { Socialization } \\
\text { sharing/dissemination } \\
\text { groups and mentoring) }\end{array} \\
\end{array}$ & $38(12.3)$ & $126(40.9)$ & $98(31.8)$ & $46(14.9)$ & 2.5065 & .89331 \\
\hline Knowledge sharing through electronic media & $38(12.3)$ & $116(37.7)$ & $117(38.0)$ & $37(12.0)$ & 2.5032 & .85989 \\
\hline Knowledge sharing culture & $34(11.0)$ & $124(40.3)$ & $109(35.4)$ & 41(13.3) & 2.4903 & .85984 \\
\hline $\begin{array}{l}\text { Externalization (knowledge sharing through } \\
\text { documentation and dissemination) }\end{array}$ & $32(10.4)$ & $126(40.9)$ & $110(35.7)$ & $40(13.0)$ & 2.4870 & .84835 \\
\hline \multicolumn{7}{|c|}{$\begin{array}{lll} & \text { Average Mean } & \text { Score }=2.53 \\
\end{array}$} \\
\hline \multicolumn{7}{|c|}{ Knowledge Creation/Sensing Processes } \\
\hline $\begin{array}{l}\text { Individual/group knowledge creation through } \\
\text { brainstorming }\end{array}$ & $47(15.3)$ & $110(35.7)$ & 107(34.7) & $44(14.3)$ & 2.5195 & .91830 \\
\hline $\begin{array}{l}\text { Mentoring programs for human capacity } \\
\text { development and youth empowerment }\end{array}$ & $30(9.7)$ & $119(38.6)$ & $117(38.0)$ & 42(13.6) & 2.4448 & .84665 \\
\hline $\begin{array}{l}\text { Extra-organizational knowledge creation to } \\
\text { support innovation and development }\end{array}$ & $31(10.1)$ & $111(36.0)$ & $119(38.6)$ & $47(15.3)$ & 2.4091 & .86641 \\
\hline \multicolumn{7}{|c|}{$\begin{array}{lll} & \text { Average Mean } & \text { Score }=2.46 \\
\end{array}$} \\
\hline \multicolumn{7}{|l|}{ Knowledge Capture/Organizing } \\
\hline Research and development projects & $32(10.4)$ & $142(46.1)$ & $105(34.1)$ & $29(9.4)$ & 2.5747 & .80163 \\
\hline Knowledge repository management & $27(8.8)$ & $117(38.0)$ & 132(42.9) & $32(10.4)$ & 2.4513 & .79549 \\
\hline $\begin{array}{l}\text { Expert knowledge capture for strategic } \\
\text { development }\end{array}$ & $25(8.1)$ & $120(39.0)$ & 122(39.6) & $41(13.3)$ & 2.4188 & .82108 \\
\hline $\begin{array}{l}\text { Open innovation and externalization of } \\
\text { knowledge }\end{array}$ & $28(9.1)$ & $110(35.7)$ & $130(42.2)$ & $40(13.0)$ & 2.4091 & .82796 \\
\hline \multicolumn{7}{|c|}{ Average Mean Score $=2.46$} \\
\hline
\end{tabular}


Table 3: Extent of Innovation Management practices in the Niger Delta

\begin{tabular}{|c|c|c|c|c|c|c|}
\hline Survey items & $\begin{array}{c}\text { Very high } \\
\text { extent }\end{array}$ & $\begin{array}{c}\text { High } \\
\text { extent }\end{array}$ & $\begin{array}{l}\text { Moderate } \\
\text { extent }\end{array}$ & $\begin{array}{l}\text { Low } \\
\text { extent }\end{array}$ & Mean & SD \\
\hline \multicolumn{7}{|l|}{ Feedback/Refinement } \\
\hline Project monitoring and evaluation & $81(26.3)$ & $106(34.4)$ & $84(27.3)$ & $37(12.0)$ & 2.7500 & .97818 \\
\hline $\begin{array}{l}\text { feedback on project progress and } \\
\text { development }\end{array}$ & $84(27.3)$ & $95(30.8)$ & $79(25.6)$ & $50(16.2)$ & 2.6916 & 1.04258 \\
\hline $\begin{array}{l}\text { Refinements and modification of projects } \\
\text { where necessary }\end{array}$ & $47(15.3)$ & $118(38.3)$ & $93(30.2)$ & $50(16.2)$ & $2.5267 \times 0$ & .93918 \\
\hline \multicolumn{7}{|c|}{ Average Mean Score $=2.66$} \\
\hline \multicolumn{7}{|l|}{ Exploitation/execution } \\
\hline Project completion and documentation & $51(16.60$ & $129(41.9)$ & $97(31.5)$ & $31(10.1)$ & 2.6494 & .87329 \\
\hline $\begin{array}{l}\text { Implementation and actual development } \\
\text { of concepts into projects, products and } \\
\text { services }\end{array}$ & $58(18.8)$ & $125(40.6)$ & $81(26.3)$ & $44(14.3)$ & 2.6396 & .94644 \\
\hline Project execution and development & $45(14.6)$ & $128(41.6)$ & $100(32.5)$ & $35(11.4)$ & 2.5942 & .87355 \\
\hline \multicolumn{7}{|c|}{ Average Mean Score $=2.63$} \\
\hline \multicolumn{7}{|l|}{ Implementation } \\
\hline Project/product commissioning & $83(26.9)$ & $101(32.8)$ & $54(17.5)$ & $70(22.7)$ & 2.6396 & 1.10815 \\
\hline Project/product launch and deployment & $65(21.1)$ & $113(36.7)$ & $83(36.9)$ & $47(15.3)$ & 2.6364 & .98071 \\
\hline $\begin{array}{l}\text { Project/product management and } \\
\text { maintenance }\end{array}$ & $43(14.0)$ & $112(36.4)$ & $100(32.5)$ & $53(17.2)$ & 2.4708 & .93561 \\
\hline Project/product commercialization & $40(13.0)$ & $99(32.1)$ & $109(35.4)$ & $60(19.5)$ & 2.3864 & .94304 \\
\hline \multicolumn{7}{|c|}{ Average Mean Score $=2.53$} \\
\hline \multicolumn{7}{|l|}{ Concept feasibility } \\
\hline Appraisal of projects concepts & $50(16.2)$ & $102(33.1)$ & $114(37.0)$ & $42(13.6)$ & 2.5195 & .92184 \\
\hline $\begin{array}{l}\text { Determination of return on investment of } \\
\text { concepts and projects }\end{array}$ & $47(15.3)$ & $107(34.7)$ & $111(36.0)$ & $43(14.0)$ & 2.5130 & .91486 \\
\hline $\begin{array}{l}\text { Determination of concept feasibility } \\
\text { determination }\end{array}$ & $38(12.3)$ & $109(35.4)$ & $128(41.6)$ & $33(10.7)$ & 2.4935 & .84458 \\
\hline $\begin{array}{l}\text { Determination of cost and benefit of } \\
\text { concepts }\end{array}$ & $31(10.1)$ & $124(40.3)$ & 113(36.7) & $40(13.0)$ & 2.4740 & .84420 \\
\hline \multicolumn{7}{|c|}{ Average Mean Score $=2.5$} \\
\hline \multicolumn{7}{|l|}{ Idea generation definition } \\
\hline $\begin{array}{l}\text { Mentoring and brainstorming programs } \\
\text { employed to enhance idea generation and } \\
\text { product development }\end{array}$ & $41(13.3)$ & $114(37.0)$ & $126(40.9)$ & $27(8.8)$ & 2.5487 & .83152 \\
\hline $\begin{array}{l}\text { Utilization of } \mathrm{R} \& \mathrm{D} \text { results/report for } \\
\text { projects and products development }\end{array}$ & $38(12.3)$ & $103(33.4)$ & $132(42.9)$ & $35(11.4)$ & 2.4675 & .85166 \\
\hline Creativity and strategic thinking & $43(14.0)$ & $108(35.1)$ & $107(34.7)$ & $50(16.2)$ & 2.4675 & .92500 \\
\hline \multicolumn{7}{|c|}{ Average Mean Score $=2.49$} \\
\hline \multicolumn{7}{|l|}{ Concept development } \\
\hline $\begin{array}{l}\text { Development of creative idea into } \\
\text { products concept }\end{array}$ & $41(13.3)$ & $128(41.6)$ & $98(31.8)$ & $41(13.3)$ & 2.5487 & .88467 \\
\hline Strategic alliance from open innovation & $37(12.0)$ & $113(36.7)$ & $118(38.3)$ & $40(13.0)$ & 2.4773 & .86714 \\
\hline $\begin{array}{l}\text { Development of expert knowledge from } \\
\text { mentoring and brainstorming sessions into } \\
\text { concept }\end{array}$ & $36(11.7)$ & $116(37.7)$ & $105(34.1)$ & $51(16.6)$ & 2.4448 & .90251 \\
\hline Implementation of R\&D projects & $31(10.1)$ & $116(37.7)$ & $112(36.4)$ & 49(15.9) & 2.4188 & .87486 \\
\hline \multicolumn{7}{|c|}{ Average Mean Score $=2.47$} \\
\hline & & & & & & \\
\hline
\end{tabular}


Table 4: Influence of Knowledge Management Processes on Job Creation in the Niger Delta

\begin{tabular}{|l|c|c|c|c|c|}
\hline \multirow{2}{*}{ Model } & Unstandardized Coefficients & Standardized Coefficients & \multirow{2}{*}{ S } & Sig. \\
\cline { 2 - 5 } & $\mathrm{B}$ & Std. Error & Beta & 7.755 & .000 \\
\hline (Constant) & 13.986 & 1.804 & .645 & 14.745 & .000 \\
KM Processes & .648 & .044 & & \\
$\mathrm{R}^{2}=.415$, & & & \\
Adjusted $\mathrm{R}^{2}=.413$, & & & \\
$\mathrm{F}(1,306)=217.418,+$ & & & \\
$\mathrm{P}<.05$ &
\end{tabular}

\section{Dependent Variable: Job creation}

\section{Conclusion and practical applications}

The study revealed that the level of knowledge management practices in the Niger Delta region was high and knowledge utilization contributed the most to it. We found that knowledge management practices influenced job creation in the region through at a slow paced. The extent of innovation management practices was also high and this has contributed to employment creation in the region. It was recommended that authority of the Niger Delta Development Commission (NDDC) should strive to maintain their level of knowledge and innovation management practices with a view to improving employment generation and general development of the area.

\section{References}

Desouza, K. C. (2011). Knowledge management: An introduction. New York: Neal-Schuman Publishers, Inc.

Epetimehin, F. M. \& Ekundayo, O. (2011). Organisational knowledge management: survival strategy for Nigeria insurance industry. Interdisciplinary Review of Economics and Management, 1(2), 9-15.

Eyinla, M. P., \& Ukpo, J. (2006). Nigeria: The travesty of oil and gas wealth. Lagos: The Catholic Secretariat of Nigeria.

Hamm, S. (2009). Is Silicon Valley losing its magic? Business Week, January 12, 28-33.

IAEA (2013). Corporate Knowledge Management Policy.

Jantunen, A. (2005). Knowledge-processing capabilities and innovative performance: an empirical study. European Journal of Innovation Management, 8(3), 336-349.

Khurana, V. K., \& Saini, A. K. (2017). Management of technology \& innovation for economic growth and development.

Kibet, K. S., Samuel C. K., Magutu P.O., \&Richard, N. B. (2010). Knowledge management as source of sustainable competitive advantage: Comparative assessment of Egerton University farms and private commercial farms. African. Journal of. Business. Management. (AJBUMA), 1, 70-83.

Menon, T., \&Pfeffer, J. (2003).Valuing internal vs. external knowledge explaining the preference for outsiders.Management Science 49(4): 497.

NACETEM (2010). Assessment of innovation capability in the manufacturing sector in Nigeria. Monograph Series, No 4: NACETEM

National Centre for Technology Management (NACETEM), (2011). Nigeria's national innovation survey2005 2007. Monograph Series, No 6: NACETEM

National Bureau of Statistics (NBS). (2016).Job creation survey, 4th Quarter 2015 and 1st Quarter 2016.

Omotayo, F. O. (2015). Knowledge management as an important tool in organisational management? A review of literature. Library Philosophy and Practice (e-journal),12(38),1-23.

Niek D du Preez \& Louis Louw (2008) A Framework for managing the innovation process Stellenbosch University, Department of Industrial Engineering, South AfricaIndutech (Pty) Ltd, Brandwacht Office Park, South Africa

Pancholi, N., \& Amrata, P (2014). Designing a conceptual framework of knowledge management process in Banks.Journal of Business and Management, 16, 114-126.

Rodrigo, D. G.,\&Manoel, F. M. (2017). Knowledge management process: A theoretical-conceptual research. São Carlos, 24(2), 248-265.

Romijn, H., \&Albaladejo, M. (2002).Determinants of innovation capability in small electronics and software firms in Southeast England.Research Policy,31, 1053-1067.

Saini, A. K., \& Khurana, V. K. (2018). Business model innovation in the digital era: issues and challenges. Digitalization, 29

Ughakpoteni, P. (2012).Main props and obstacles to the implementation of the Niger Delta Regional Development Master Plan (NDRDMP) by the Niger Delta Development Commission. Thesis submitted in accordance with the requirements for the degree of Master of Arts in Leading Innovation and Change.York St John University at Robert Kennedy College. 
UNDP (2014). UNDP knowledge management strategy framework2014-2017: 8 .

UNESCO (2012).Knowledge management for culture and development. Culture Sector of the United Nations Educational, Scientific and Cultural Organization, 1-21.

WIPO (2015). The knowledge management strategy of the World Intellectual Property Organization, 2015-2018, Information document (A/55/INF/5):4.

Wong, K. Y.,\&Aspinwall, E. (2006). Development of a knowledge management initiative and system: a case study. Expert Systems with Applications, 30(4), 633-641. 